\title{
On Influence of Cultural Difference of British and American Literary Criticism
}

\author{
Wei Li \\ Baoshan College of Traditional Chinese Medical, Baoshan Yunnan, 678000, China
}

Keywords: Cultural difference, British and American literature, Literary Criticism, Influe.

\begin{abstract}
Culture is usually generated with human history and changes with the development and progress of human society. It has extensive and profound influence to human social activity, which would affect Literary Criticism to change it under the influence of cultural difference. Starting from the development of British and American literature as well as British and American Literary Criticism, this article explores the influence of cultural difference to British and American Literary Criticism and hopes to provide corresponding support and reference to the study of British and American Literary Criticism.
\end{abstract}

\section{Introduction}

Culture is generated at the early stage of human history and has quite extensive influence to production and life of the public. However, influenced by different national surroundings and geographic variation, during the long-term development process, culture starts to show obvious nationality difference and makes world culture to present obvious diversified development tendency to some extent. Under the current background of multi-culture synergetic development, British and American Literary Criticism is influenced by many factors and culture is one of the most important factors. Thus, to study the British and American Literary Criticism, it should attach importance to British and American cultural differences, further explore British and American Literary Criticism based on British and American cultural differences and make British and American literature research work to acquire greater progress.

\section{Development of British and American Literature and British and American Literary Criticism}

There is the important relation between British and American literature development and British and American Literary Criticism. British and American Literary Criticism could even be regarded as developed by the appearance of British and American literature. Thus, in order to study British and American Literary Criticism, it should be with the help of British and American literature to socioculture and life in Britain and America, based on two nations' cultural differences to enhance deep-going Literary Criticism research work, guarantee to acquire greater research result and provide corresponding support to the worldwide spread and development of British and American literature.

\section{Development of British and American literature}

As to a nation, classical literature is the reflect of national wisdom and thus the British and American literature could be regarded as crystal of people's wisdom in Britain and America, which is the outward manifestation of British and American culture in literature field. From broad sense, British and American literature not only represent artistry gathering of two national languages of Britain and America but also manifest artistry of real life of the people in these two countries. It plays the important role of advertising and inheriting British and American culture in the world and is the 
significant channel to know and study British and American culture for world people. As the important communication tool in Britain and America, English is usually applied in literatures to convey spirit ideology and emotional connotation of writer or even people in Britain and America ${ }^{[1]}$. Comparing to the development of British and American literature, since the founding time of Britain was earlier with longer development of literature, successively going through Anglo-Saxon period, renaissance, neo-classicism, romanticism, realism, Modernism and postmodernism, British literature emitted its unique artistic charms in different literature development periods which had significant influence to the development of world literature. Especially with the ending of the Second World War, English literature went forward diversified development with the stimulation and influence of the current world culture and showed up new development characteristics in new period. American literature was influenced by its immigrant nature and founding time, not only developing with shorter time but also influenced by many countries' cultures during development process with more obvious diversification characteristic. After $19^{\text {th }}$ century, American literature gradually break away from English literature and became independent. After one century's development, American literature gradually presented prosperity and development tendency in $20^{\text {th }}$ century, which could keep pace with English literature and be called British and American literature to occupy important location in world literature. At the same time, American literature was influenced by the Second World War during development process as well and appeared collision and fighting of new and old cultures after war, which had some positive influence to the diversified development of American literature to some extent.

\section{British and American Literary Criticism}

British and American Literary Criticism simply refers to the practical activity deeply studying British and American literature with relevant literature theories, which could reveal development law of British and American literature, indicate directions of future development of British and American literature creation and provide corresponding reference basis to favorable development of British and American literature creation. Generally speaking, British and American Literary Criticism takes British and American literatures as main objects of study and rationally choose different critic forms according to stimuli-presenting mode of literature, such as novel commentary, traditional opera commentary, poetry criticism, essay criticism, etc. In the field of literary studies, carrying out British and American Literary Criticism is mainly to study and criticize ideological contents, writing style, etc. of British and American literatures and provide some references for appreciator to read and appreciate literatures as well as support for favorable spread of British and American Literature.

Analyzing from certain significances, there is some differences between British and American Literary Criticism and simple analysis of British and American literature. Though the former is based on the analyzing of literature, it deeply studies the ideological implication, mental shackles, etc. of literature and criticize those literatures. Specifically, analyzing work of literature lies the importance on the study of works themselves attribution, while British and American Literary Criticism on literatures' outward manifestation, ideological implication, artistic value, etc. By comprehensive analysis and evaluation to these problems, it is to propose systematic Literary Criticism viewpoints and provide certain support to the deep implementation of literature study and the wide spread of British and American literature worldwide.

\section{Influence of Cultural Difference to British and American Literary Criticism}

\section{Influence of difference in cultural connotation to British and American Literary Criticism}

There were some confusions for English Literary Criticism during long-term development, whether to inherit or get rid of the traditional culture and explore new development ways, which once became bones of contention of English Literary Criticism ${ }^{[2]}$. From $17^{\text {th }}$ to $18^{\text {th }}$ century, English Literary Criticism showed specific development tendency, influenced by the current cultural development environment to show absurd creation characteristic and obvious religious color. At this period, 
English Literary Criticism started to explore ways to get rid of the restrain of traditional culture based on the transmission of traditions, which had some influence to the development of English Literary Criticism. Entering into $20^{\text {th }}$ century, English Literary Criticism had new changes under specific environment. Literary Criticism experts started to restudy and explore the traditional Literary Criticism work and had profound influence to the development of later-age Literary Criticism. Till the modern times, future development trend of English Literary Criticism is increasingly obvious, reflecting development trend of post-colonialism, feminism and postmodernism and the working contents gradually change to the study and survey to literature theory achievement, thus hoping to provide corresponding support to the construction of new literature theory and enhancing new literature theory and social adaptation. This shows that there is close connection between development of English Literary Criticism and English specific cultural connotations, which could even be regarded that the change of British cultural connotation has direct influence to the change of English Literary Criticism.

Studying the American Literary Criticism should also pay attention to American literature and cultural connotation. The founding time of America was comparatively later and had certain immigrant nature. With influence of immigrant culture, its literature development revealed corresponding American local aborigines culture and literature characteristics in continent of Europe to some extent. English literature and Indian literature had the most obvious influence to American literature. During long-term development process, American literature gradually dynamically integrated continent culture of Europe, immigrant culture and Indian culture and began to show personalized development tendency ${ }^{3]}$. Similarly, based on literature influence, American Literary Criticism would inevitably receive Literary Criticism of European continent, especially the influence of British Literary Criticism. But such influence had no absoluteness. Under the driven of different cultural connotations, there was characteristic Literary Criticisms of American literature during development process. Comprehending British Literary Criticism and American Literary Criticism and analyzing, British Literary Criticism receives more obvious influence of traditional literary connotation and thus keeps hesitation and struggle during development process. Though with some innovations, emphasis is still to inherit traditional culture. And the American literature has comparatively shorter development time, which has less influence to American Literary Criticism. Thus American Literary Criticism has more obvious innovation, openness, containment, diversified development tendency and gets extensive approval all over the world.

\section{Influence of cultural language to British and American Literary Criticism}

Language plays important carrier role in cultural transmission process, is also the main method for a nation to manifest this national culture. Influenced by national development history and geographical environment, national cultures formed by different nations have wide differences which would affect the national culture and Literary Criticism in language. With British and American Literary Criticism as the example and influenced by literary creation language, British and American Literary Criticism shows different development tendency with the influence of British English and American English. Thus in order to analyze influence of cultural difference to British and American Literary Criticism, it should pay attention to grasp the difference in British and American standard speech ${ }^{[4]}$.

British culture has a long history, relatively rich national cultural deposits and English is the important carrier of British national culture. The development of English not only shows the inheritance of traditional British culture but also prompt the representation of British literature. Such characteristic causes that during the criticism process of some experts to British literature, because of hopes and fears to English, this old language, the used criticism language is rather precise, usually without insolent languages. Thus British Literary Criticism has not obvious freedom of personality, with certain cultural inheritance.

As the important derivative language of British English, American English is inevitably influenced by British English, whose core still continues idea of British English. However, America is a country of immigrants, insists independent, freedom and equal thoughts during development 
process and changes its own economic, cultural and political system and standard during process of pursuing national independence. Such changes influence American English - carrier of national culture and gradually shows treason and innovative characteristic. Specifically, under the influence of American national culture, Literary Criticism has some difference from British preciseness, which pays more attention to extending individuality and innovative thoughts, with nation and freedom as main idea and even showing the positive cultural spirit of "everything is possible" .

To sum up, it shows that differences in carriers of culture would also influence the British and American Literary Criticism. Thus to study British and American Literary Criticism, it should also pay attention to linguistic differences to guarantee comprehensiveness of study.

\section{Influence of difference in culture and history to British and American Literary Criticism}

Deeply studying and analyzing the English literature could show that its cultural historical tradition belongs to humanism. However, influenced by history of development of British literature, humanism in British cultural history is proposed relative to theocratic socialism and asceticism, which is different from the modern humanism thought. Thus in British literature, humanism thoughts are usually relatively conservative and even the activities to spread humanism thoughts from broad sense. Such viewpoint generates extensive and profound influence to British Literary Criticism and prompt it get certain development ${ }^{[5]}$. But with further development of society, influenced by its own conservatism, humanism thoughts in British Literary Criticism gradually receives query and negation from part researchers who think that if the society wants some development, it should get help of revolutionary power. Only to insist revolution could it provide corresponding power support for social revolution. Under such influence, humanistic thought in British Literary Criticism gets severe shock and even once make the work go wrong way.

With the influence of American cultural history, American Literary Criticism shows certain humanism idea, insisting the radical idea and meanwhile paying attention to originality of Literary Criticism which make American Literary Criticism get certain progress. This is because American Literary Criticism receives two factors' influence. On the one hand, cultural development of American history is with shorter time, without heavy cultural cloth-wrappers. On the other hand, America has gone through the process of pursuing democracy and independence during development process, and thus American Literary Criticism is affected by this thought, with obvious humanism tendency and even innovation to humanism thought.

\section{Conclusion}

To sum up, during the development process of British and American literature and Literary Criticism, there are many factors to affect British and American Literary Criticism, and cultural factor is the vitally important constituent part. Only to study from cultural difference could it guarantee comprehensiveness of study, correctly guide sustainable development of British and American Literary Criticism and make it acquire greater achievement in new period.

\section{References}

[1] Gai Yingying, Influence of Cultural Difference to British and American Literary Criticism, Times Literary, 2012(4): 183-184.

[2] Wu Jin, Influence of British and American Cultural Difference to British and American Literary Criticism, Intelligence, 2015(3): 282-283, 285.

[3] Zhang Wei, On Influence of British and American Cultural Difference to British and American Literary Criticism, Xijiang River, 2014(12): 444-444.

[4] Zhang Huining, On Influence of Cultural Difference to British and American Literary Criticism, Overseas English (Fisrt), 2015(1): 8-9, 14. 
[5] Zhang Yao, Influence of British and American Cultural Difference to British and American Literary Criticism, Jounal of Heilongjiang College of Education, 2015 (8): 99-100. 